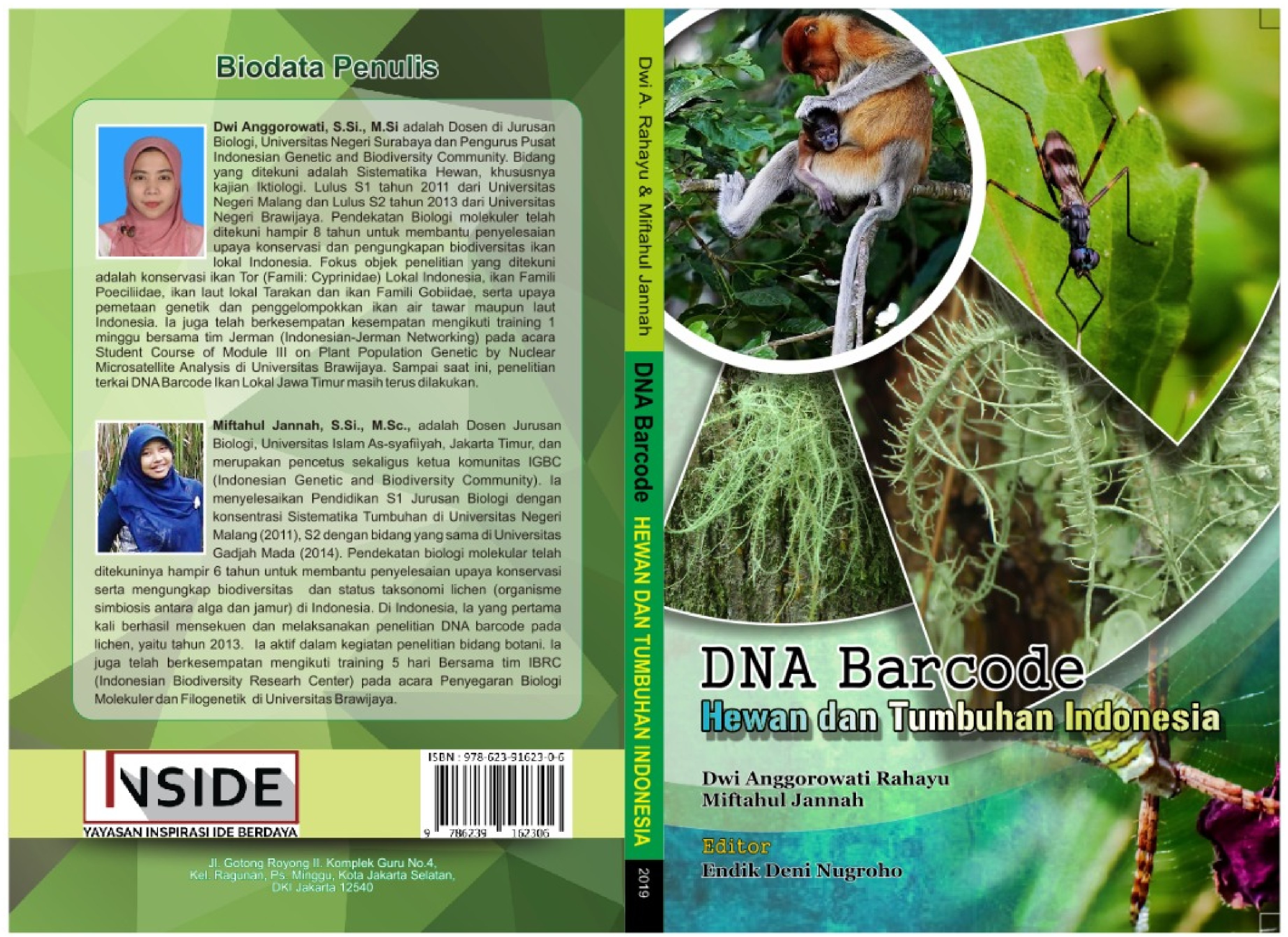




\section{DNA BARCODE \\ HEWAN DAN TUMBUHAN INDONESIA}

Oleh :

Dwi Anggorowati Rahayu, S.Si., M.Si

Miftahul Jannah, S.Si., M.Sc

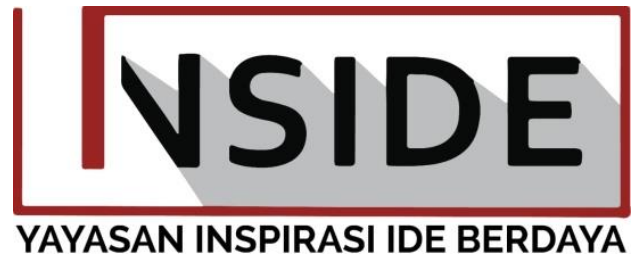




\section{DNA BARCODE HEWAN DAN TUMBUHAN INDONESIA}

Penulis:

Dwi Anggorowati Rahayu, S.Si., M.Si

Miftahul Jannah, S.Si., M.Sc

Editor

Endik Deni Nugroho, S.Pd., M.Pd

Desain Sampul

Khalid Mawardi, ST

Diterbitkan Oleh

Yayasan Inspirasi Ide Berdaya

Jl. Gotong Royong II. Komplek Guru No.4,

Kel. Ragunan, Ps. Minggu,

Kota Jakarta Selatan, DKI Jakarta 12540

v, 165 hal., Illus, $17.6 \times 25$

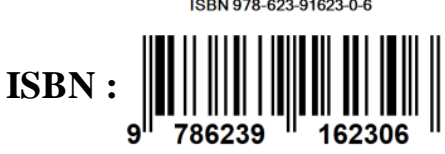

copyright (C) 2019 Yayasan Inspirasi Ide Berdaya

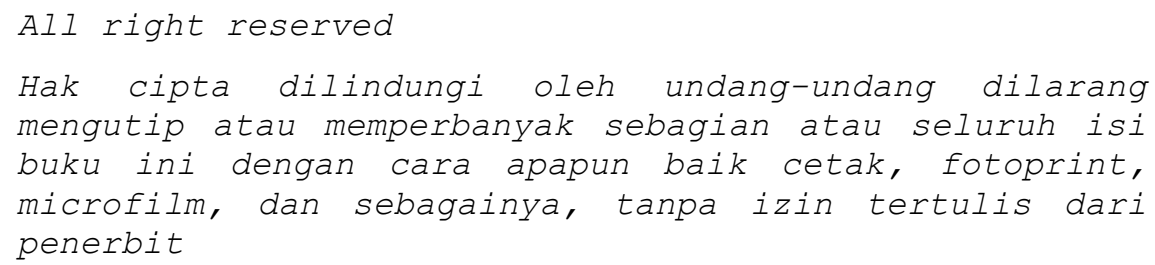




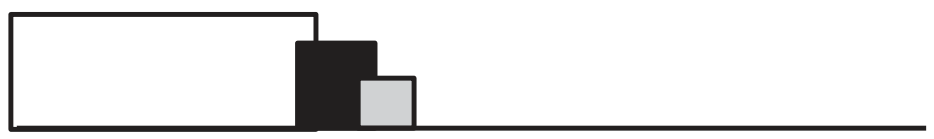

\section{KATA PENGANTAR}

Dewasa ini dunia telah dihadapkan pada masalah ancaman krisis keanekaragaman hayati (biodiversitas) dan sebagian besar ancaman itu berada di Negara tropis Indonesia. Minimnya informasi biodiversitas di Indonesia, memunculkan kekhawatiran beberapa spesies hayati punah sebelum dikenali. Lamanya proses identifikasi membuat spesies Flora dan Fauna tertentu mati sebelum terekam data base-nya. Kurangnya informasi biodiversitas Flora dan Fauna yang diperlukan untuk tujuan konservasi dan pemanfaatan, ditengarai dengan kurangnya ahli taksonomi untuk memberikan informasi kekayaan hayati dan potensinya di Negeri ini.

Pendekatan molekuler (marka molekuler spesifik-spesies) dan DNA Barcode akan memberikan alternatif cepat dan tepat mengungkap spesies Tumbuhan dan Hewan lokal dan Endemik Indonesia. Penentuan nama spesies secara tepat akan membuka peluang jangka panjang penerapan konservasi in situ maupun ex-situ Fauna lokal Indonesia. Buku ini akan memberikan penyegaran, inspirasi dan acuan bagi mahasiswa dan peneliti Indonesia untuk terbuka dan bergegas segera menyelamatkan plasma nutfah Indonesia yang belum terdeskripsikan. Buku ini merupakan curahan dari pengalaman penulis dalam belajar dan praktek langsung tentang taksonomi dan sistematika molekuler.

Buku ini berisi tentang hal penting terkait DNA Barcode dan tahapan analisis genetik DNA Barcode coding dan non coding region yang sangat dibutuhkan oleh peneliti yang bergerak di bidang taksonomi dan evolusi suatu spesies. Buku ini akan menjadi sebuah buku yang bisa dimanfaatkan oleh taksonom Indonesia. Karya ini masih jauh dari sempurna, sehingga kritik dan saran dari pembaca sangat diperlukan. Semoga buku ini memberikan banyak manfaat kepada pembaca, pemerhati keanekaragaman hayati Indonesia dan kemajuan pendidikan Indonesia.

25 Agustus 2019

Dwi Anggorowati Rahayu

Miftahul Jannah 


\section{DAFTAR ISI}

KATA PENGANTAR

DAFTAR ISI

DAFTAR GAMBAR

$\mathrm{Vi}$

DAFTAR TABEL

vi

\section{BAB 1. DNA BARCODE DALAM TAKSONOMI MOLEKULER}

1.1 Pengertian DNA Barcode

1.2 Sumber Data DNA Barcode

1.3 Pentingnya DNA Barcode

1.3 DNA Barcode Hewan

1.4 DNA Barcode Tumbuhan 10

1.5 Alur Kerja DNA Barcode

1.6 Peranan DNA Barcode dalam taksonomi

1.7 Prinsip dan Aplikasi Analisis Fenetik dan Filogenetik

\section{BAB 2. METODE ANALISIS DNA}

2.1 Teknik Identifikasi Molekuler Tumbuhan

2.2 Teknik Identifikasi Molekuler Hewan

\section{BAB 3. TAHAPAN ANALISIS DNA BARCODE (CODING DAN NON CODING REGION}

3.1. Analisis DNA Barcode Coding Region Pada Hewan

3.2. Analisis DNA Barcode Pada Tumbuhan

BAB 4. Studi Kasus DNA Barcode pada Hewan

BAB 5. Studi Kasus DNA Barcode pada Tumbuhan 


\section{Bab 1}

\section{DNA BARCODE DALAM TAKSONOMI MOLEKULER}

\subsection{Pengertian DNA Barcode}

Seiring dengan kemajuan pesat biologi molekuler, gen COI pada genom mitokondria menjadi starting point dalam penelitian taksonomi dan filogenetika molekuler. Gen COI menjadi marka spesifik-spesies untuk identifikasi secara molekuler khususnya pada hewan, sedangkan ITS, mat-k dan rbcl untuk tumbuhan. DNA Barcode menjadi pusat perhatian taksonom dunia, karena

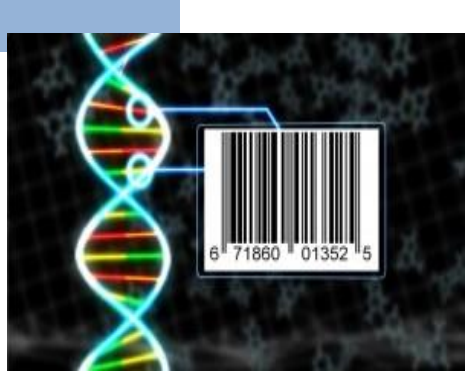
memiliki 2 tujuan, yaitu untuk identifikasi molekuler yang sudah terdeskripsikan maupun spesies yang belum terdeskripsikan. Sebelum mengupas tuntas penelitian identifikasi molekuler menggunakan DNA Barcode, kita akan pahami terlebih dahulu pengertian DNA Barcode dan sejarah DNA Barcode hingga menjadi starting point dalam dunia taksonomi molekuler.

DNA barcode merupakan suatu teknik menggunakan sekuen DNA yang berukuran pendek, yang digunakan untuk mempercepat dan mempermudah proses identifikasi suatu spesies. Identifikasi organisme yang pada awalnya hanya berdasarkan karakter morfologi saat ini telah berkembang kearah taksonomi molekular, dimana pengelompokan dilakukan berdasarkan kemiripan gen yang dimiliki organisme. Namun, DNA barcode yang telah ada saat ini tidak bisa dipakai bagi tumbuhan secara universal, karena adanya keragaman yang sangat tinggi pada tumbuhan. DNA barcode merupakan salah satu pendekatan yang dapat digunakan untuk menganalisis variasi genetik. DNA barcode dapat memberikan kontribusi kuat untuk penelitian keanekaragaman hayati dan taksonomi.

Hebert et al. (2003) menyatakan bahwa DNA Barcoding adalah urutan sekuen pendek DNA yang telah terstandarisasi untuk identifikasi spesies hewan secara tepat, cepat, dan akurat, sedangkan Petit \& Excoffier (2009) mendeskripsikan DNA Barcode sebagai sekuen pendek DNA yang telah terstandarisasi digunakan untuk identifikasi dan penemuan spesies secara cepat. Hal ini dapat disimpulkan bahwa DNA Barcode dicirikan sebagai urutan sekuen pendek DNA yang "unik", sehingga menunjukkan variasi genetik di dalam setiap spesies, juga diantara spesies. Teknik DNA Barcode dapat digunakan untuk mengidentifikasi semua bentuk tingkatan kehidupan mulai dari telur, larva, pupa sampai dewasa.

Casiraghi et al. (2010) menjelaskan bahwa DNA Barcode adalah alat molekuler dan bioinformatika untuk identifikasi spesies biologi. Awal mula ide dasar pemanfaatan DNA Barcode adalah untuk analisis variabilitas marka molekuler terstandar, dapat memungkinkan untuk membedakan identitas taksa hingga tingkat spesies. Metode ini didasarkan pada asumsi bahwa variasi genetik di antara spesies melebihi variasi di dalam spesies. Analisis DNA Barcode yang ideal mencerminkan distribusi variabilitas intraspesies dan interspesies, memberikan peluang yang sangat cepat dan akurat sebagai marker untuk identifikasi berbagai variasi taksa dan mengungkapkan beberapa kelompok hewan yang belum diketahui tingkat taksonominya (Rahayu \& Nugroho, 2016). 
Perintis pertama kali penggunaan DNA Barcode adalah Dr. Paul Hebert dan kawan-kawan. Beliau berasal dari Universitas Guelph, Kanada pada tahun 2003. Beliau berhasil mengidentifikasi dan mendeferensiasi spesies (yang berasal dari sepihan, potongan organ, bahkan pradewasa suatu organisme) dengan hanya menggunakan sekuen gen pendek. Publikasi Hebert dkk. telah menggemparkan para ahli taksonomi, genetik dan biologi evolusi dunia pada saat itu. Barcode dengan sekuen pendek dari genom mitokondria diibaratkan seperti mesin scanner yang biasa digunakan di supermarket untuk mengetahui identitas dari suatu barang dengan tepat dan cepat. Jika dua organisme dilihat dengan kasat mata merupakan organisme yang sangat mirip, namun berbeda dengan kasus penggunaan DNA Barcode tersebut.

Karakteristik DNA barcode yaitu sekuen DNA bersifat ortolog, memiliki variablitas yang cukup untuk membedakan antar spesies, dan dapat menunjukkan variablitas rendah dalam individu yang termasuk spesies yang sama. Pemilihan jenis DNA barcode dalam studi taksonomi harus memperhatikan beberapa hal yaitu harus ada dalam semua taksa yang dibandingkan, memiliki pengetahuan tentang gen atau wilayah genom lainnya untuk mengembangkan primer, tingkat evolusi gen harus sesuai dengan tingkat takson yang diteliti, mudah dilakukan alignment, dan bersifat homolog (Kress et al, 2005; Virgilio, 2012). DNA barcode dapat diperoleh dari inti (nDNA), kloroplas (cpDNA) dan mitokondria (mtDNA). Masing-masing sekuen DNA barcode memiliki karakteristik yang spesifik. DNA barcode inti (nDNA) antara lain ITS, 18S, 26S, adh; sedangkan DNA barcode klroplas antara lain rbcL, ndhF, atpB, matK, rpl16 (Kress et al, 2007).

\subsection{Sumber DNA Barcode}

Sumber sekuen DNA yang digunakan dalam taksonomi molekuler dapat diperoleh dari inti (nDNA), kloroplas (cpDNA), dan mitokondria DNA (mtDNA). Tabel 1 dibawah ini menunjukkan spesifikasi gen yang dapat digunakan sebagai karakter dalam identifikasi spesies:

Tabel 1. Sumber DNA Barcode

\begin{tabular}{ll}
\hline \multicolumn{1}{c}{ Gen } & Lokasi Genom \\
\hline COI-barcode (cytochrome-c oxidase sub unit I) & Mitokondria \\
16 S-rDNA & Mitokondria \\
Cyt-b (Cytochrome b) & Mitokondria \\
ITS1-rDNA(Internal Trancribed Spacer) & Inti \\
ITS 2-rDNA(Internal Trancribed Spacer) & Inti \\
18S-rDNA & Inti \\
rbcL (Large Sub Unit of Riboluse 1,5- biphospate carboxyl- & Plastida \\
aseloxygenase) & \\
matK & Gen di kloroplas \\
\hline
\end{tabular}

Gen yang banyak digunakan sebagai penanda barcode tersebut dari gen pengkode protein antara lain cytochrome c oxidase I (COI) dan cytochrome b (cyt-b), sedangkan dari gen RNA ribosom adalah $12 \mathrm{~S}$ rRNA dan $16 \mathrm{~S}$ rRNA. Penggunaan gen ribosom biasanya untuk taksa yang lebih tinggi, seperti tingkat suku (famili) atau marga (ordo), sedangkan gen pengkode protein dapat berada pada tingkat spesies maupun subspesies hingga spesies yang memiliki kekerabatan sangat dekat sekalipun. 
Sekuen DNA yang sering digunakan dalam penelusuran hubungan kekerabatan, penelusuran evolusi suatu spesies, dan sistematika molekular adalah DNA mitokondria (Solihin, 1994; Ward dkk., 2005; Hidayat dan Pancoro, 2006). Hal ini dikarenakan DNA mitokondria memiliki laju mutasi sepuluh kali lipat lebih tinggi daripada DNA inti, tidak memiliki intron, jarang terjadi rekombinasi, DNA mitokondria bersifat monofiletik, diturunkan secara maternal dalam bentuk haploid berdasarkan garis keturunan maternal, DNA mitokondria memiliki jumlah salinan DNA yang sangat banyak dalam organelnya, dan pada sel yang sama terdapat 100-10.000 salinan genom mitokondria. Oleh sebab itu, untuk mengisolasi DNA mitokondria lebih mudah daripada DNA inti (Saccone dkk., 1999; Rubinoff, 2005). Selain itu, pencarian filogenetik sering menggunakan DNA mitokondria karena sangat berguna dalam mempelajari hubungan spesies dan taksa yang baru saja bercabang (Hebert dkk., 2003; Rubinoff dkk., 2005 dalam Rahayu \& Nugroho, 2016).

DNA mitokondria hewan secara umum memiliki jumlah dan jenis gen yang sama yaitu terdiri atas 37 gen, dengan 13 gen pengkode protein (URF1,URF2,URF3, URF5, URF6, URFA6L, URF4L, Cytochrome Oxidase Unit 1, Cytochrome Oxidase II, Cytochrome Oxidase Unit III, Cytochrome b, dan ATP ase 6), 22 gen pengkode transfer RNA (tRNA) dan 2 gen ribosomal (12S rRNA dan 16S rRNA) (Solihin, 1994). Setiap gen memiliki karakter tersendiri dalam penelusuran hubungan kekerabatan suatu spesies. Gen 12S rRNA merupakan gen yang conserved, sering digunakan untuk penelusuran kekerabatan pada level tertinggi (filum dan sub filum), gen 16S rRNA sering digunakan pada kategori pertengahan (tingkat famili dan genus); gen pengkode protein termasuk gen yang relatif conserved, penanda yang kuat, sehingga sering digunakan untuk analisis keragaman genetik pada katagori yang lebih rendah (famili, genus dan spesies), salah satunya adalah gen COI merupakan gen yang relatif conserved, menempati posisi tertinggi ketiga yang mengalami substitusi pada basa nukleotidanya, hal inilah yang mengarahkan laju mutasinya menjadi tiga kali lipat lebih besar dibandingkan dengan gen $12 S$ rRNA dan $16 S$ rRNA (Knowlton \& Weight, 1998; Popa dkk., 2007); dan gen daerah pengkontrol (D-loop) yang merupakan non coding region, berpengaruh dalam replikasi dan translasi mitokondria, segmen DNA yang memiliki tingkat hipervariasi yang tinggi dalam penelusuran ditingkat spesies maupun sub spesies (Arif dkk., 2009 dalam Rahayu \& Nugroho, 2016).

\subsection{Pentingnya DNA Barcode dalam Sistematika}

Indonesia merupakan salah satu negara yang memiliki keanekaragaman hayati sangat besar (Mega Biodiversity) di dunia setelah Brazil. Tingkatan Indonesia untuk keragaman jenis hewan, seperti: mamalia adalah tertinggi di dunia (515 spesies, $36 \%$ spesies endemik), terbesar ketiga utuk keragaman jenis reptilia (lebih dari 600 spesies), terbesar keempat untuk jenis burung (1519 spesies, $28 \%$ endemik), terbesar kelima untuk jenis amphibi (270 spesies), ikan air tawar (1000 spesies) yang ditemukan di perairan Indonesia, serta luasnya kawasan perairan teritorial Indonesia yang merupakan kawasan laut terkaya di wilayah Indo-Pasifik juga mendukung kekayaan habitat laut dan terumbu karang, akan tetapi belum semua spesies tersebut teridentifikasi.

Pemanfaatan keanekaragaman hayati secara langsung bukan tidak mengandung resiko. Banyak unsur yang mempengaruhi masa depan keanekaragaman hayati Indonesia, seperti juga tantangan yang harus dihadapi dalam proses pembangunan nasional secara keseluruhan, khususnya jumlah penduduk yang besar dan menuntut tersedianya berbagai kebutuhan dasar. Peningkatan kebutuhan dasar tersebut menyebabkan sebagian areal hutan alam berubah fungsi dan menyempit, dengan rata-rata pengurangan 15.000-20.000 hektar per tahun (Soeriaatmadja, 1991). Kawasan di luar hutan yang mendukung 
kehidupan keanekaragaman hayati seperti daerah persawahan dan kebun-kebun rakyat berubah peruntukan dan cenderung menjadi miskin keanekaragaman hayatinya.

Kerusakan habitat dan eksploitasi yang berlebihan, tidak mengherankan jika Indonesia memiliki daftar spesies terancam punah terpanjang di dunia, yang mencakup 126 jenis burung, 63 jenis mamalia dan 21 jenis reptil lebih tinggi dibandingkan Brasil. Sejumlah spesies dipastikan telah punah pada tahuntahun terakhir ini, termasuk trulek jawa/trulek ekor putih (Vanellus macropterus) dan sejenis burung pemakan serangga (Eutrichomyias rowleyi) di Sulawesi Utara, serta sub spesies harimau (Panthera tigris) di Jawa dan Bali. Populasi spesies yang saat ini sangat rentan terhadap ancaman penjarahan dan lenyapnya habitat cukup banyak.

Permasalahan diatas memicu untuk dicari jalan keluar bagaimana cara yang paling cepat dan tepat untuk mengungkapkan keanekaragaman hayati di dunia ini sebelum mengalami kepunahan. Hal ini ternyata juga di latar belakangi dari kurangnya ahli taksonomi diseluruh dunia. Ahli taksonomi yang terbatas hanya dapat mengidentifikasi ketika suatu spesimen yang diteliti masih dalam bentuk utuh. Hal ini yang menyebabkan persoalan pengungkapan identitas spesies terkendala lama. Observasi lapangan menunjukkan bahwa banyak spesimen yang ditemukan terkadang rusak menjadi serpihan dan organisme belum dewasa yang sangat sulit sekali dikenali bentuk aslinya. Sehingga, diperlukan suatu terobosan ide yang cepat, tepat, dan akurat melalui metode DNA Barcoding.

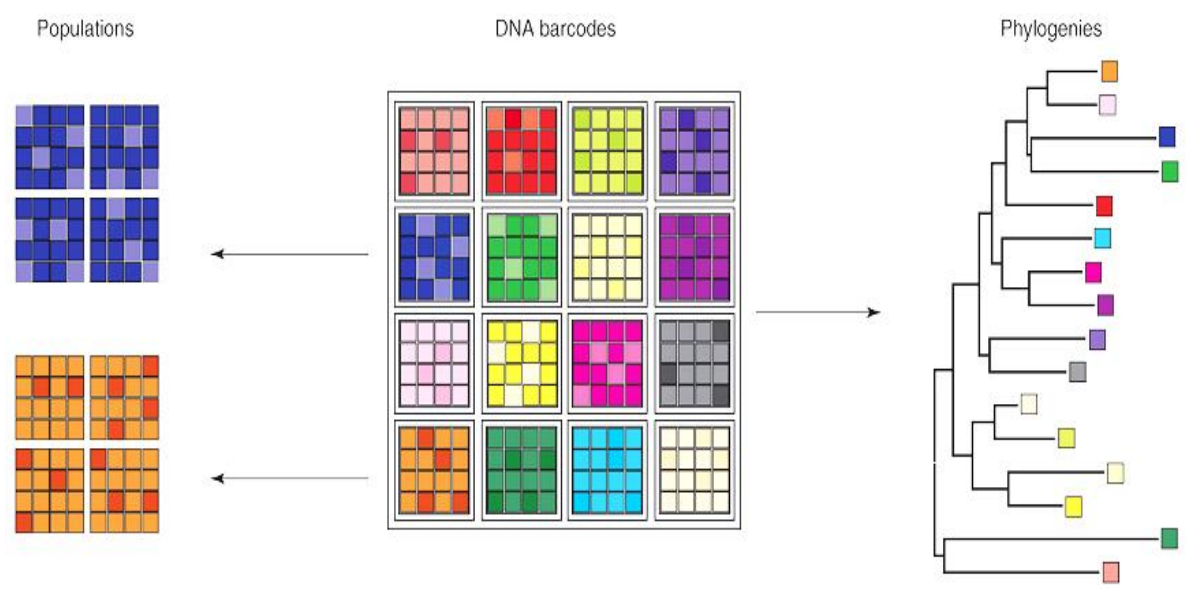

Gambar 2. Posisi relatif DNA Barcode terletak antara genetika populasi dan filogenetika (Hajibabaei et al., 2007). Setiap kotak kecil mewakili satu individu. Perbedaan warna menunjukkan perbedaan spesies dan perbedaan di dalam spesies ditunjukkan dengan variasi bayangan warna.

Analisis perbandingan sekuen DNA saat ini digunakan pada hampir semua bidang ilmu biologi, dari biologi perkembangan sampai epidemiologi, namun cabang biologi yang telah mengembangkan aplikasi yang digunakan untuk menilai kekerabatan biologi dengan sekuen DNA adalah filogenetika molekuler dan genetika populasi. Kedua bidang kajian tersebut memiliki fokus yang berbeda. Kajian filogenetika molekuler biasanya berurusan dengan hubungan evolusioner antara clades yang lebih rendah, sedangkan target genetika populasi adalah variasi di dalam dan di antara populasi dari spesies tunggal. DNA Barcode menempati posisi tengah dengan fokus pada penggambaran daripada kekerabatannya. 
Frezal dan Leblois (2008) merinci kegunaan DNA Barcode sebagai berikut:

1. DNA Barcode sebagai pendukung domains sains (ekologi, biomedik, epidemiologi, biologi evolusi, biogeografi, biologi konservasi, dan bio-industri).

2. DNA Barcode meningkatkan kemampuan survai yang bertujuan untuk deteksi spesies dan identifikasi spesies patogen yang berperan dalam bidang medik, ekologi dan agronomi

3. Dapat mengenali, mendeteksi, melacak keberadaan organisme paten pada agrobioteknologi.

4. DNA Barcode digunakan sebagai determinasi identitas taksonomi suatu taksa tertentu.

\subsection{DNA Barcode Hewan}

Penanda Barcoding pada hewan yang sering digunakan adalah sekuen barcode gen cytochrome-c oxidase I (COI) dengan panjang sekitar $648 \mathrm{bp}$. COI memberikan peluang yang sangat cepat dan akurat sebagai marker untuk identifikasi berbagai variasi taksa dan mengungkapkan beberapa kelompok hewan yang belum diketahui tingkat taksonominya (Popa dkk., 2007 \& Arief dkk., 2009). Gen COI merupakan potongan DNA yang terdapat di dalam membran mitokondria, serta berfungsi untuk mengatur proses pernafasan di dalam sel dengan cara mengkatalis reduksi $\mathrm{O} 2$ dan memompa proton melalui membran secara simultan. Potongan DNA ini terdapat di dalam rantai pernafasan eukariot dan sebagian besar bakteri (Rahman, 2011).

Gen COI memiliki 2 keuntungan yang penting, (1) primer-primer universal untuk gen ini memiliki kemampuan sangat kuat, yaitu mampu mencakup ujung 5' dari sebagian besar atau keseluruhan filum hewan (Folmer dkk., 1994 \& Zhang, 1997), (2) gen COI memiliki rentangan sinyal filogenetik yang lebih besar dibandingkan dengan gen mitokondrial lainnya. Evolusi pada gen ini cukup cepat untuk menunjukkan perbedaan tidak hanya untuk spesies yang berkerabat dekat, tetapi juga antara kelompok phylogeographic dalam spesies tunggal (Cox \& Hebert 2001; Wares \& Cunningham 2001 dalam Hebert dkk., 2003). Gen COI memberikan pandangan filogenetik yang lebih mendalam dibandingkan gen mitokondrial lainnya seperti Cyt-b (Simmon \& Waller, 2001), karena perubahan sekuen asam amino terjadi lebih lambat (Lynch \& Jarrell 1993). Selain itu, tidak ditemukan adanya insersi, delesi maupun stop kodon, sehingga mendukung standart identifikasi spesies hewan (Hajibabaei dkk., 2007 dalam Rahayu \& Nugroho, 2016).

Analisis polimorfisme dengan menggunakan sekuen DNA memanfaatkan adanya "primer universal" pada daerah genom mitokondria (mtDNA) (Palumbi dkk.,1994). Daerah ini menyediakan resolusi yang besar terhadap variabilitas genetik dan memiliki kemampuan yang dalam dibidang sistematika molekuler (Arnason et al., 2002). Gen COI memiliki primer universal yang sangat kuat untuk mengamplifikasi ujung 5' dari sebagian besar atau keseluruhan filum hewan yang menjadikan target spesifik dalam taksonomi. Primer spesifik tersebut telah di rancang oleh Palumbi dkk. (1991) dengan susunan basa COIf (5'-CCTGCAGGAGGAGGA GAYCC-3') dan COIe (5'CCAGAATTAGAGGGAATCAGTG-3'). Dibawah ini adalah daerah primer universal untuk mengamplifikasi daerah spesifik dari gen COI sebagai berikut:

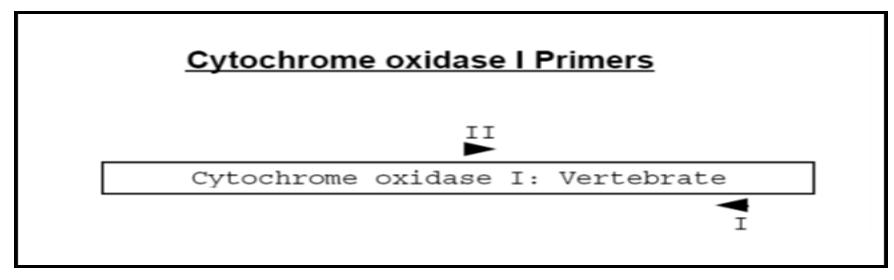

Gambar 3. Daerah spesifik gen COI sebagai standar identifikasi hewan 
Kode I dan II adalah daerah primer spesifik untuk mengamplifikasi Barcode gen COI. Kelebihan gen COI dibandingkan gen lainnya:

1. Panjang sekuen gen ini relatif pendek, sekitar 648 bp yang mampu membedakan variasi intraspesies maupun interspesies.

2. Relatif stabil, tidak mudah mengalami perubahan bila dibandingkan dengan gen yang lain.

3. Gen ini sangat cocok digunakan untuk menentukan identitas spesies, karena mempunyai tingkat variabilitas yang rendah (1-2\%), bahkan untuk suatu kelompok spesies yang memiliki tingkat kekerabatan sangat dekat hanya memiliki perbedaan beberapa persen saja.

4. Memiliki jumlah kopi yang banyak, sehingga mudah diamplifikasi di bandingkan gen yang berasal dari inti.

Berdasarkan karakter barcode gen COI tersebut, sekarang gen ini menjadi marka yang penting untuk identifikasi spesies (Dawnay et al., 2007); menyediakan tingkat efektifitas yang tinggi untuk identifikasi kupu-kupu, burung, ikan, lalat, dan kelompok hewan lainnya (Hebert et al., 2003), mengukur tingkat keanekaragaman global (Arif et al., 2003), memiliki potensi untuk memperbaiki keanekaragaman hewan liar dan membedakan spesies yang belum jelas kedudukannya (Pegg et al., 2006). Gen COI relatif tetap (conserved) pada ikan, menunjukkan level yang rendah terhadap variasi intraspesies, dan sebagai indikator yang baik untuk menelusuri hubungan genetik (Ward et al., 2008).

Tahun 2005, perikanan dipilih sebagai target utama untuk cakupan barcode dunia terkait kepentingan sosial ekonomi, sehingga saat ini lebih dari 5000 spesies telah berhasil diidentifikasi (Wong \& Hanner, 2008). Hal ini mencakup baik ikan air tawar (Hubert dkk. 2008) maupun ikan laut (Rock dkk., 2008), sehingga teknik DNA barcoding memainkan peranan yang sangat penting sebagai alat bantu taksonomi untuk mengungkap secara genetik spesies yang berbeda dan terpisah secara cepat dan akurat. Gen COI ini sudah digunakan untuk identifikasi ikan air tawar di Kanada (Hubert et al., 2008), ikan laut di Australia termasuk didalamnya kelompok ikan teleostei, hiu dan pari (Ward et al., 2005), dan ikan air tawar dari Meksiko dan Guatemala (Moreno et al., 2009). Selain itu, gen tersebut juga digunakan untuk identifikasi larva ikan yang tinggal di perairan Australia, dan identifikasi ikan sebelum tahap dewasa yang mencakup perkembangan mulai dari telur sampai tahap dewasa (Rock et al., 2008) dan mampu membedakan Tor duoronensis dan Tor tambraides di Sarawak sebagai spesies yang berbeda, yang ditunjang dengan pembentukan clade tunggal yang tidak saling tumpang tindih (Esa et al., 2008).

Selain untuk identifikasi spesies, sekuen barcode gen COI juga membantu penemuan spesies baru, analisis biodiversitas, konservasi, identifikasi hama, analisis filogenetik (Ribak, 2010), forensic engineering (Dawney et al., 2007) dan ekologi dari komunitas yang belum jelas (Hubert et al., 2008). Webb dkk. (2004) juga menggunakan sekuen barcode gen COI untuk merekonstruksi pohon filogenetik dari beberapa taksa ikan. Penelitian yang dilakukan oleh Maralit et al. (2012) membuktikan bahwa ikan yang dikaji "Pigek" dan "Bulidao" merupakan spesies yang sama yaitu Mesopristes cancellatus yang ditunjukkan dari hasil topologi pohon filogenetik bahwa keduanya membentuk clade yang sama. 


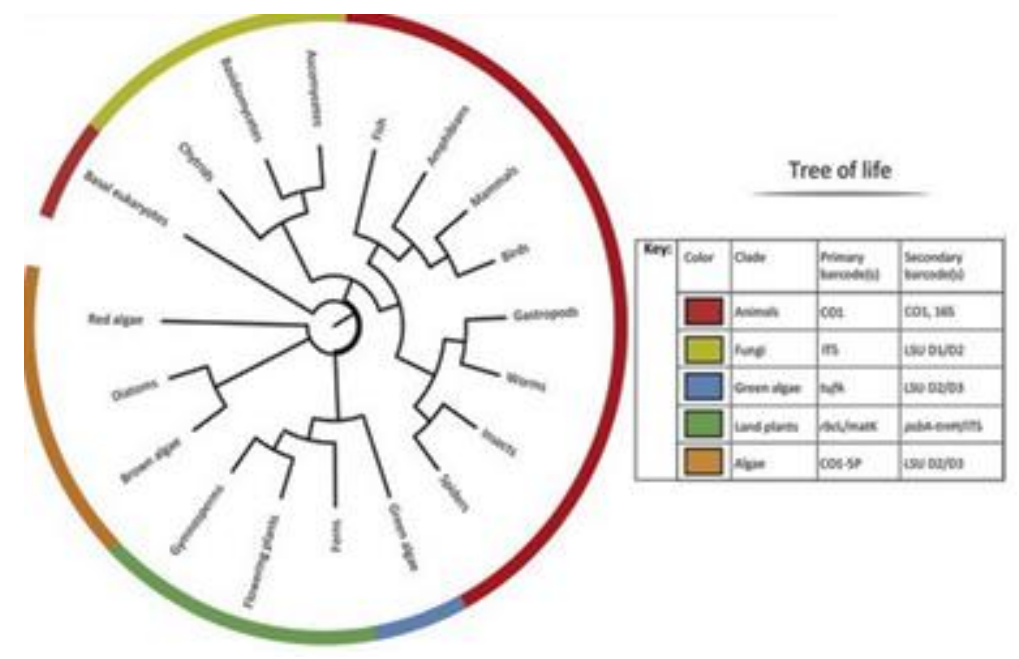

Gambar 4. Sumber DNA Barcode (Wong \& Hanner, 2008)

Metode DNA barcoding memiliki keunggulan lebih murah dan lebih cepat mendapatkan hasil dibandingkan metode berbasis DNA yang lainnya (Wong \& Hanner 2008). Diantara seluruh keuntungan tersebut metode ini sangat berharga dengan kecepatannya dan kehandalannya dalam proses autentikasi produk komersial (Rahman, 2011). Kelebihan lain dari penggunaan sekuen barcode gen COI adalah adanya data base yang disebut The Barcode of Life Data System (Ratnasingham dkk., 2007). Data base ini menyimpan dan memberikan informasi data berupa hasil sekuen barcode gen COI, data spesimen, tingkatan taksonomi spesies, primer yang digunakan, penelusuran kekerabatan, dan barcode dari gen tersebut. Peneliti dari seluruh belahan dunia dapat dengan mudah mengakses maupun memasukkan data hasil penelitiannya. The Barcode of Life Data System juga memiliki klasifikasi dari masing-masing proyek barcoding seperti Barcoding of Fish (FishBol), Barcoding of Birds, Barcoding of Earthworms, dan Barcoding of Mamals of the Word (www.barcodinglife.org). The Barcode of Life Data System memberikan interpretasi sekuen gen yang terdapat dalam BOLD system dalam bentuk barcode (Ratnasingham dkk., 2007).

\subsection{DNA Barcode Tumbuhan}

DNA barcode merupakan suatu Teknik menggunakan sekuen DNA yang berukuran pendek, yang digunakan untuk mempercepat dan mempermudah proses identifikasi suatu spesies. Identifikasi organisme yang pada awalnya hanya berdasarkan karakter morfologi saat ini telah berkembang kearah taksonomi molekular, dimana pengelompokan dilakukan berdasarkan kemiripan gen yang dimiliki organisme. Namun, DNA barcode yang telah ada saat ini tidak bisa dipakai bagi tumbuhan secara universal, karena adanya keragaman yang sangat tinggi pada tumbuhan. DNA barcode merupakan salah satu pendekatan yang dapat digunakan untuk menganalisis variasi genetik. DNA barcode dapat memberikan kontribusi kuat untuk penelitian keanekaragaman hayati dan taksonomi.

Karakteristik DNA barcode yaitu sekuen DNA bersifat ortolog, memiliki variablitas yang cukup untuk membedakan antar spesies, dan dapat menunjukkan variablitas rendah dalam individu yang termasuk spesies yang sama. Pemilihan jenis DNA barcode dalam studi taksonomi harus memperhatikan beberapa hal yaitu harus ada dalam semua taksa yang dibandingkan, memiliki pengetahuan tentang gen atau wilayah genom lainnya untuk mengembangkan primer, tingkat evolusi gen harus sesuai dengan 
tingkat takson yang diteliti, mudah dilakukan alignment, dan bersifat homolog (Kress et al, 2005; Virgilio, 2012). DNA barcode dapat diperoleh dari inti (nDNA), kloroplas (cpDNA) dan mitokondria (mtDNA). Masing-masing sekuen DNA barcode memiliki karakteristik yang spesifik. DNA barcode inti (nDNA) antara lain ITS, 18S, 26S, adh; sedangkan DNA barcode klroplas antara lain rbcL, ndhF, atpB, matK, rpl16 (Kress et al, 2007).

DNA kloroplas (cpDNA) memiliki karakteristik yaitu: mempunyai genom berukuran kecil dan struktur yang stabil, (2) genom lebih konservatif dengan rata-rata subtitusi nukleotida yang rendah dan (3) genom tidak mengalami rekombinasi dan diturunkan secara uniparental. DNA kloroplas (cpDNA) berbentuk lingkaran dengan rentang ukuran 85-2000 kilobasa (kb). cpDNA mengontrol produksi RNA transfer (tRNA), RNA ribosomal (rRNA), dan sebagian besar protein yang terdapat di dalam organel kloroplas (Cumming et al, 2003).

Gen rbcL berukuran panjangs ekitar 1400 bp sehingga menyediakan banyak karakter untuk kajian filogenetik (CBOL, 2009). Peranan gen rbcL yang mengkode protein RuBisCO diduga menyebabkan sekuen gen ini memiliki tingkat mutasi yang rendah dibandingkan dengan gen barcode lain dalam cpDNA sehingga tingkat kesamaan antar spesies cukup tinggi. Tingkat mutasi yang rendah ini memberikan keuntungan untuk kajian mendalam tentang variasi genetik dan filogenetik interspesies (Cumming et al, 2003).

Gen matK banyak digunakan dalam studi taksonomi dan filogenetik baik intraspesies maupun interspesies pada angiospermae (Samuel et al, 2006). Gen ini memiliki peran dalam pemasakan, memiliki Panjang sekuen \pm 1500 bp dan terletak diantara intron kloroplas pada gen trnK (Simpson, 2006). Kecepatan substitusi gen matK 3 kali lebih tinggi pada level nukleotida dan 6 kali lebih tinggi pada level asam amino bila dibandingkan dengan gen rbcL (Hilu \& Liang, 1997; Hilu \& Barthet, 2007).

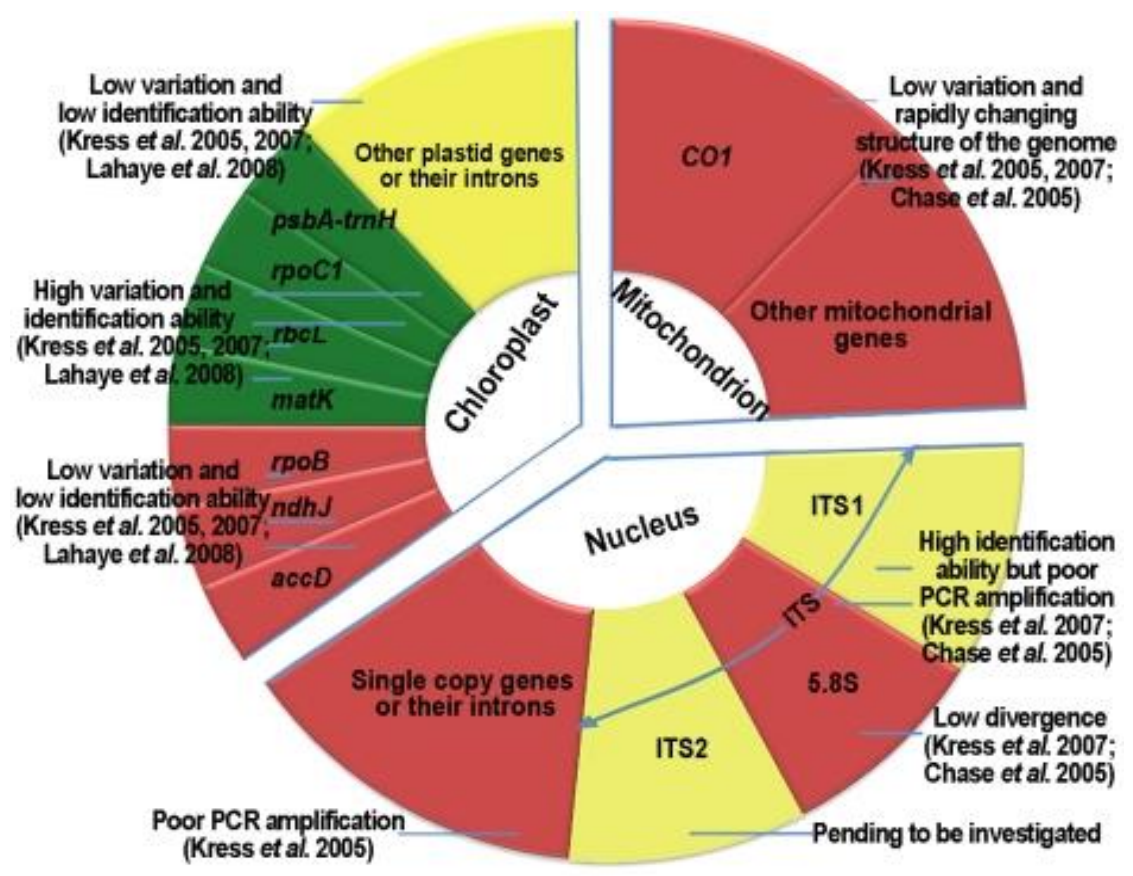

Gambar 5. Sumber DNA Barcode pada Tumbuhan (Kress et al., 2007).

Salah satu contoh DNA barcode dari derah inti yang sering digunakan yaitu Sekuen ITS (Internal Transcribed Spacer) nuclear ribosomal DNA (nrDNA) (Divakar et al., 2006; Del-Prado et al., 2006; 
Articus et al., 2004; Serusiaux, 2009). Sekuen ITS dapat membedakan inter dan intra spesies serta penelusuran hubungan kekerabatan dengan melihat perbedaan daerah conserved dan melihat similaritas daerah variabel. Ribosomal DNA adalah suatu daerah dalam nuklear DNA yang mengkode ribosom. Ribosom merupakan organel sel yang berperan dalam sintesis protein dan terdiri dari subunit kecil (18S) dan subunit besar (28S). Urutan nukleotida rDNA berisi dua daerah non-coding (ITS1 dan ITS2) dan gen 5,8S rDNA. Urutan nukleotida pada gen 5,8S rDNA sangat conserved, tetapi dua daerah ITS lainnya tidak ditranslasi menjadi protein dan sangat bervariasi (Articus et al., 2004). Sekuen ITS rDNA terdiri dari daerah yang evolusioner dan mempunyai derajat variasi yang lebih tinggi dibandingkan daerah lain di rDNA.

\subsection{Alur Kerja DNA Barcode}

Identifikasi spesies melalui DNA Barcode biasanya dilakukan dengan pengambilan sekuen pendek (sebagai barcode) dari suatu bagian genome yang terstandar (yaitu wilayah gen yang spesifik). Sekuen barcode dari spesimen yang tidak diketahui kemudian dibandingkan dengan pustaka sekuen barcode yang berasal dari individu yang sudah diketahui identitasnya (Gambar.4). Gambar tersebut menunjukkan bagaimana "pustaka" barcode dapat mendukung alur kerja taksonomi melalui "high throughput identification" spesimen yang belum diketahui dan melalui bantuan pemberian gambaran spesies baru atau spesies criptic'. Sekuen barcode dan data tambahan untuk setiap spesimen dapat diakses melalui database secara online (BOLD system: www. barcodinglife.org). Informasi tersebut dapat berguna untuk filogenetika (proyek tree of life) dan kajian tingkat populasi. Sebagai tambahan, arsip DNA dan jaringan spesimen dikoleksi oleh proyek Barcoding guna menyediakan sumber daya penelitian lain. Pada Gambar 4 ditunjukkan, sebuah spesimen dapat diidentifikasi jika cocok dengan salah satu pustaka barcode. Jika tidak akan menjadi catatan sekuen barcode baru pada spesies tertentu (yaitu suatu haplotipe baru atau varian geografis), atau dapat diduga sebagai suatu spesies baru (Hajibabei et al., 2007).

Prinsip dasar Gambar 6, DNA Barcoding berkontribusi terhadap penelitian taksonomi, genetika populasi, dan filogenetika. Pada taksonomi, DNA Barcoding dapat digunakan untuk rutinitas identifikasi spesimen, juga memperjelas atau memperkuat penelitian taksonomi yang komprehensif. Pada penelitian filogenetika, DNA Barcoding dapat digunakan sebagai starting point untuk pemilihan taksa secara optimal. Pada penelitian genetika populasi, DNA Barcoding menyediakan suatu first signal untuk kajian divergensi populasi dan memfasilitasi kajian perbandingan diversitas populasi pada berbagai spesies. Hajibabei (2007) menyimpulkan bahwa DNA Barcode dapat memberikan kontribusi yang kuat untuk penelitian taksonomi dan keanekaragaman hayati, jika sekuen DNA Barcode terakumulasi, maka data tersebut akan memberikan prespektif genomik "horizontal" yang unik dengan implikasi yang luas.

Hajibabaei et al. (2007) berpendapat bahwa meskipun perannya dalam mengidentifikasi spesimen ke tingkat spesies cukup penting pada alur kerja taksonomi, DNA Barcode bukan sebagai pengganti untuk analisis taksonomi yang komprehensif. Apabila sebuah spesimen yang belum diketahui tidak ada catatan yang sesuai pada pustaka barcode, sekuen barcode tersebut tidak memenuhi syarat untuk menjadi spesies baru. Sebaliknya, spesimen tersebut sangat perlu dianalisis taksonomi secara menyeluruh. Bila dilihat dalam konteks kerangka kerja taksonomi tradisional yang biasanya jauh lebih lambat dibandingkan analisis barcode, spesimen tersebut sangat berpotensi menjadi temuan spesies baru. 


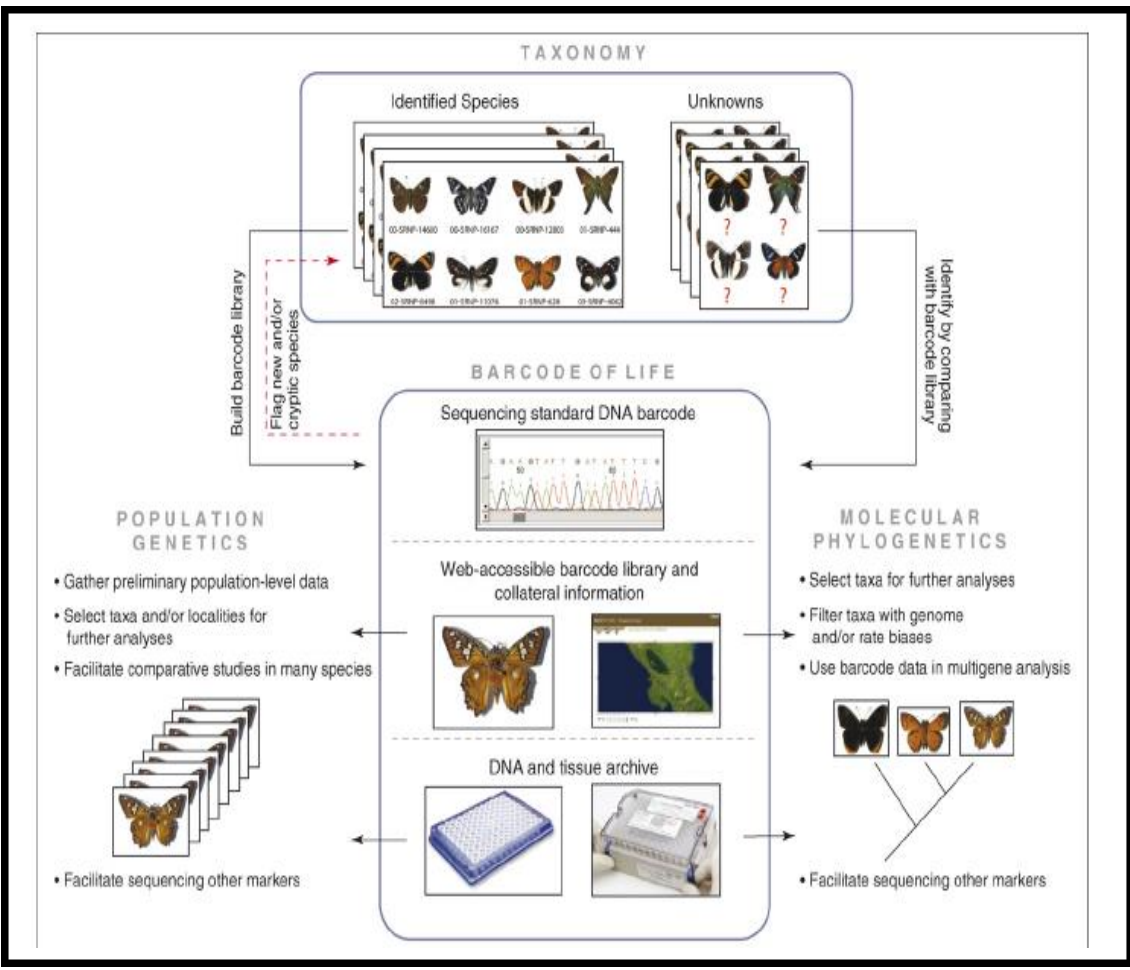

Gambar 6. Komponen Barcode of life dan kontribusinya terhadap taksonomi, rekonstruksi filogenetik molekuler, dan penelitian genetika populasi (Hajibabei et al., 2007).

Perkembangan teknologi DNA Barcode menyebabkan teknik ini semakin luas digunakan dalam bidang taksonomi dan konservasi spesies. DNA Barcode memiliki peran penting dalam penilaian keanekaragaman hayati, baik untuk masa sekarang maupun masa lalu. Hal ini dapat dilakukan melalui identifikasi spesies suatu jenis organisme tertentu. Berbicara tentang taksonomi pasti berkaitan dengan deskripsi, identifikasi, pemberian nama baru suatu taksa atau spesies, menata organisme (takson) menjadi suatu sistem klasifikasi, serta membuat kunci identifikasi spesies tersebut. Hal yang menjadi point terpenting penggunaan DNA Barcode dalam taksonomi adalah karakter basa nukleotida yang "unik" atau automorfi (basa nukleotida yang hanya dimiliki oleh spesies tertentu) yang membedakannya dengan spesies lain. Variasi basa nukleotida tersebut akan mendeferensiasi spesies menjadi bagian kelompoknya secara alami.

Beberapa alasan digunakan DNA Barcode dalam taksonomi antara lain:

1. DNA Barcode membantu menyelesaikan masalah tumpang tindih karakter variasi intra dan interspesies (cryptic spesies/mirip)

2. DNA Barcode membantu memecahkan identifikasi di berbagai tingkat kehidupan organisme (telur, larva, dan dewasa).

3. DNA Barcode dapat membantu menemukan, membedakan, dan mendeskripsi spesimen yang sulit diidentifikasi dengan karakter morfologi.

4. DNA Barcode mengurangi kerancuan identifikasi spesies

Marka molekuler DNA Barcode diharapkan dapat membantu menggugah semangat para taksonom dunia, khususnya peneliti Indonesia untuk mengungkap spesies yang belum terdeskripsikan dan 
spesies samar yang sulit diidentifikasi dengan cepat. DNA Barcode akan memainkan peranan yang sangat penting sebagai alat bantu taksonomi, karena kemampuannya yang cepat dan tepat untuk mengungkap secara genetik jenis yang berbeda dan terpisah jauh.

\subsection{Peranan DNA Barcode dalam Taksonomi}

Identifikasi dengan menggunakan marka atau ciri-ciri morfologi (kunci-kunci determinasi) masih banyak dilakukan oleh ahli taksonomi. Hal tersebut, karena identifikasi berdasarkan data morfologi sebagai dasar awal yang digunakan untuk menentukan nama spesies. Pengamatan harus dilakukan terhadap seluruh bagian dari organisme yang akan diidentifikasi, seperti misalnya pada tumbuhan, harus diamati seluruh organ, seperti karakter organ daun, batang, akar, bunga, buah, dan biji. Hasil pengamatan ini kemudian dibandingkan dengan koleksi spesimen di database atau herbarium, serta dicocokan dengan deskripsi yang ada ada dalam buku identifikasi.

Identifikasi spesies berdasarkan karakter morfologis memiliki beberapa kendala, yaitu pada bebderapa takson hanya bisa dilakukan untuk tumbuhan dewasa (berbunga), sehingga memerlukan watu yang lama untuk pengambilan sampel dan pengamatan harus menunggu masa berbunga atau berbuah (Virgilio et al. 2012). Pada beberapa organisme seperti lichen genus Usnea, Karakter morfologis, anatomis, dan kimiawi secara luas hanya dapat digunakan untuk membedakan tingkat famili dan genus. Hal ini karena karakter morfologis Usnea sangat dipengaruhi oleh lingkungan, sehingga bukan merupakan karakter yang stabil untuk dasar pembeda antar spesies. Divakar et al. (2006) menyatakan, terdapat kasus sibling spesies, karena secara morfologi sangat sedikit karakter pembeda antar spesies, misalnya $U$. florida dan $U$. subfloridana hanya dapat dibedakan berdasarkan ada tidaknya organ reproduksi. Perbedaan yang mencolok dari kedua spesies tersebut yakni $U$. florida memiliki lebih banyak organ reproduksi seksual, sedangkan $U$. subfloridana dengan organ reproduksi aseksual. Organ reproduksi lichen seperti apotesia merupakan karakter yang baik untuk identifikasi tingkat spesies, namun mengalami pertumbuhan yang sangat lambat selama fase hidup, sehingga menjadi kendala untuk identifikasi (Clerc, 1998; Swinscow \& Krog, 1978).

Identifikasi dengan marka molekular melalui DNA barcode memberikan alternatif identifikasi yang cepat, akurat, dan tepat. Analisis molekular diperlukan untuk memperkuat dan mendukung identifikasi spesies secara morfologi. Hal ini dikarenakan karakter molekular lebih stabil terhadap pengaruh lingkungan. Identifikasi dengan menggunakan sekuen DNA Barcode telah meningkat pesat dan telah dilakukan pada semua tingkatan takson, misalnya famili, genus, dan spesies. Beberapa keunggulan Identifikasi dengan DNA barcode, yaitu memerlukan jumlah sampel yang sedikit, dapat diambil dari semua organ baik tumbuhan atau hewan, tidak tergantung umur dewasa atau muda, dapat mengidentifikasi dan menunjukkan variasi yang tidak dapat dilakukan dengan pengamatan morfologi.

Perkembangan teknologi DNA Barcode menyebabkan teknik ini semakin luas digunakan dalam bidang taksonomi dan konservasi spesies. DNA Barcode memiliki peran penting dalam penilaian keanekaragaman hayati, baik untuk masa sekarang maupun masa lalu. Hal ini dapat dilakukan melalui identifikasi spesies suatu jenis organisme tertentu. Berbicara tentang taksonomi pasti berkaitan dengan deskripsi, identifikasi, pemberian nama baru suatu taksa atau spesies, menata organisme (takson) menjadi suatu sistem klasifikasi, serta membuat kunci identifikasi spesies tersebut. Hal yang menjadi point terpenting penggunaan DNA Barcode dalam taksonomi adalah karakter basa nukleotida yang "unik" atau automorfi (basa nukleotida yang hanya dimiliki oleh spesies tertentu) yang membedakan- nya dengan 
spesies lain. Variasi basa nukleotida tersebut akan mendeferensiasi spesies menjadi bagian kelompoknya secara alami.

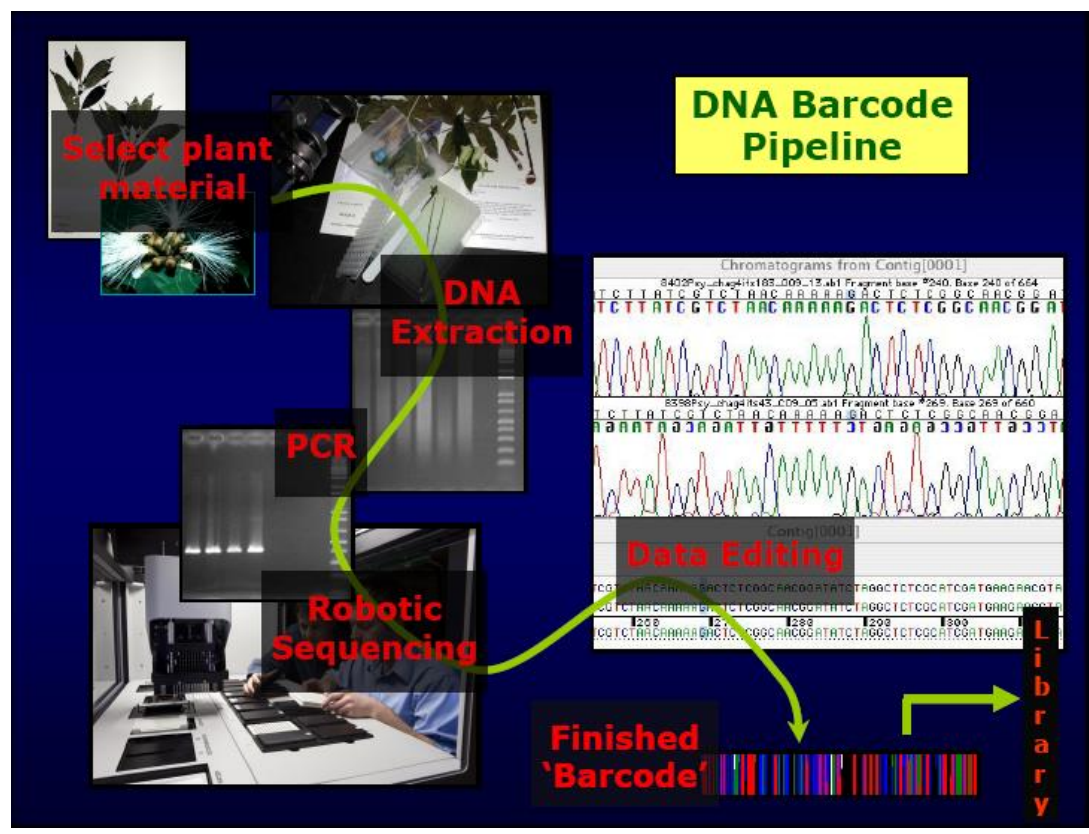

Gambar 7. Identifikasi Pipeline dengan menggunakan DNA Barcode

Beberapa alasan digunakan DNA Barcode dalam taksonomi antara

lain:

1. DNA Barcode membantu menyelesaikan masalah tumpang tindih karakter variasi intra dan interspesies (cryptic spesies/mirip)

2. DNA Barcode membantu memecahkan identifikasi di berbagai tingkat kehidupan organisme (telur, larva, dan dewasa).

3. DNA Barcode dapat membantu menemukan, membedakan, dan mendeskripsi spesimen yang sulit diidentifikasi dengan karakter morfologi.

4. DNA Barcode mengurangi kerancuan identifikasi spesies

Marka molekuler DNA Barcode diharapkan dapat membantu menggugah semangat para taksonom dunia, khususnya peneliti Indonesia untuk mengungkap spesies yang belum terdeskripsikan dan spesies samar yang sulit diidentifikasi dengan cepat. DNA Barcode akan memainkan peranan yang sangat penting sebagai alat bantu taksonomi, karena kemampuannya yang cepat dan tepat untuk mengungkap secara genetik jenis yang berbeda dan terpisah jauh.

\subsection{Prinsip dan Aplikasi Analisis Fenetik dan Filogenetik}

Secara fundamental, sistematika bertujuan untuk memahami dan mendeskripsikan keanekaragaman suatu organisme dan merekonstruksi hubungan kekerabatannya terhadap organisme lainnya, dan juga mendokumentasikan perubahan-perubahan yang terjadi di dalam masing-masing spesies. Terdapat dua macam metode dalam rekonstruksi hubungan kekerabatan antar organisme, yaitu metode fenetik dan filogenetik. Analisis fenetik merupakan salah satu pendekatan yang dapat digunakan 
untuk menentukan kekerabatan suatu tumbuhan atau hewan yang didasarkan pada kesamaan karakter atau ciri morfologi. Pendekatan fenetik disusun berdasarkan seluruh similaritas (kesamaan) pada seluruh karakter yang ada. Semakin besar kesamaan yang dimiliki, maka semakin dekat hubungan kekerabatannya, tanpa membandingkan karakter yang bersifat homologi dan homoplasi, yang digambarkan dalam bentuk dendogram. Karakter homolog yakni karakter yang diwariskan dari nenek moyang kepada keturunannya, sedangkan karakter homoplasi merupakan karakter yang diperoleh akibat dari proses adaptasi terhadap lingkungan yang sama (Lawrence, 1995; Campbell et al., 2008).

Pendekatan filogenetik merupakan klasifikasi yang disusun dengan mempertimbangkan jalur evolusi setiap organisme yang dikaji. Hal ini berbeda dengan klasifikasi fenetik yang hanya melihat hubungan antar organisme berdasarkan karakter yang ada pada saat ini. Penelusuran hubungan kekerabatan secara filogenetik dapat menggunakan data berupa urutan (sequence) nukleotida pada DNA atau karakter morfologis, dengan catatan karakter tersebut merupakan karakter yang bersifat homolog. Namun pada kenyatannya, untuk menentukan karakter homolog berdasarkan data morfologis relatif sangat sulit. Sekuen DNA yang digunakan dalam klasifikasi molekular filogenetik harus merupakan sekuen yang diwariskan langsung oleh nenek moyang (homolog) serta memiliki kesamaan sejarah evolusi. Sekuen DNA yang digunakan sebagai marka dalam rekonstruksi filogentik harus memenuhi persyaratan yaitu, bersifat homolog, memiliki daerah conserved dan variable, dan terdistribusi pada seluruh organisme. Gen 16S rRNA merupakan salah satu contoh marker molekular yang digunakan dalam klasifikasi filogenetik karena terdapat pada organisme baik yang berada pada domain Bacteria, Archaea, serta Eukarya. Informasi mengenai sekuen DNA 16S rRNA sudah sangat banyak tersedia pada database.

Terdapat tiga tahapan utama dalam rekonstruksi hubungan kekerabatan organisme berdasarkan karakter molekuler, yakni sequence alignment, rekonstruksi pohon filogenetik, dan evaluasi pohon filogenetik. Proses sequence alignment bertujuan pensejajaran sekuen DNA yang panjangnya berbeda berdasarkan posisi homolog. Proses alignment yang benar akan menghasilkan pohon yang benar. Proses ini memiliki asumsi bahwa suatu urutan DNA yang diwariskan dari nenek moyang pada keturunannya seharusnya tidak berbeda jauh dan mirip apabila dibandingkan antar satu turunan dengan lainnya (Hillis et al., 1996). Dalam rekonstruksi pohon filogenetik berdasarkan algoritme dan model evolusi tertentu. Setiap algoritme memiliki asumsi yang berbeda sehingga akan memberikan hasil pohon yang berbeda. Selain itu pemilihan outgrup juga penting untuk rekonstruksi pohon filogenetik. Penambahan outgroup bertujuan untuk membuat root pada rekonstruksi pohon filogenetik. Tujuan utama proses tersebut untuk melihat proses evolusi sejak mulai divergensi dari nenek moyang bersama. Syarat pemilihan outgroup yang baik dalam proses rooting yaitu taksa yang berada diluar ingroup, tetapi memiliki hubungan kekerabatan yang paling dekat dengan ingroup. Proses root memberikan kontribusi dalam branch length yang terbentuk. Branch length menggambarkan seberapa jauh atau dekat hubungan kekerabatan antar organisme, semakin panjang branch length maka hubungan kekerabatan semakin jauh dan berlaku sebaliknya.

Menurut Hillis et al. (1996) dan Graur \& Li (2000) dalam Jannah, 2014, metode algoritme rekonstruksi filogenetik dikelompokkan menjadi dua, yakni metode "distance-matrix" dan metode "character-based".

\section{Metode Distance Matrix}

Metode Distance Matrix merupakan suatu metode rekonstruksi pohon filogenetik menggunakan dasar nilai "pairwase distance" atau "p-distance". Metode ini memberikan nilai dekat atau jauhnya hubungan kekerabatan antar organisme pada pohon berdasarkan nilai p-distance. Semakin besar nilai pdistane maka semakin jauh hubungan kekerabatan antar organisme dan begitu sebaliknya. 


\section{Sekuen 1 = ACGATCGTAGCTAGCATCGT}

\section{Sekuen 2 = ACGAGCGTAGCTTGCATAGG}

$p$-distance $=\mathrm{n}_{d} / \mathrm{n}=4 / 20=0.2$

Gambar 8. Ilustrasi nilai p-distance (Nei \& Kumar, 2000)

Metode distance matrix yang umum dikenal meliputi: Unweighted-Pair Group Method with Arithmetic Means (UPGMA), Minimum Evolution (ME), dan Neighbor-Joining (NJ). Metode UPGMA merupakan metode tertua dan pertama kali digunakan dalam rekonstruksi pohon filogeni. Logikanya adalah indeks nilai $p$-distance terkecil antar pasangan organisme digunakan untuk menggabungkan kedua organisme tersebut dalam 1 kelompok (clade). Metode ini menghasilkan pohon ultrametik, yakni pohon yang semua organismenya memiliki jarak yang sejajar satu sama lain jika ditelusuri dari akar (root). Hal tersebut berlaku dengan asumsi, yakni jika laju evolusi antar organisme yang dibandingkan sama. Sedangkan, fakta menunjukkan bahwa laju evolusi antar organisme untuk gen yang sama tidaklah sama (Saitou \& Nei, 1987 dalam Jannah, 2014).

Metode ME dan NJ dikembangkan untuk melengkapi metode UPGMA. Kedua metode tersebut tidak menghasilkan pohon ultrametik, karena mengamsusikan laju evolusi yang berbeda antar organisme. Kekerabatan antar organisme pada suatu pohon adalah sebesar total branch length yang menghubungkan keduanya. Konsep ini membolehkan panjang branch length yang tidak sejajar antar organisme. Metode ME akan mencari pohon yang memiliki nilai tree length terkecil. Tree length yaitu panjang total pohon yang merupakan jumlah total dari semua branch length. Metode ME akan mengevaluasi setiap pohon berdasarkan nilai tree length untuk mencari pohon terbaik.

Metode NJ menggunakan asumsi yang hampir sama dengan UPGMA dengan sedikit modifikasi menghilangkan ultrametisitas. Metode ini mencari pohon terbaik berdasarkan nilai tree length terkecil. Metode ini memiliki asumsi bahwa nilai tree length terkecil dari suatu pohon dapat dicapai dengan branch length terkecil, sehingga sedikit berbeda dengan metode ME (Saitou \& Nei, 1987 dalam Jannah, 2014). Keuntungan metode NJ waktu komputasi yang lebih cepat, sehingga direkomendasikan untuk menganalisis organisme dalam jumlah yang banyak.

\section{Metode Character-Based}

Metode Character-Based menggunakan urutan nukleotida secara langsung dalam rekonstruksi pohonnya. Kelompok metode ini mencakup metode Maximum-Parsimony (MP) dan MaximumLikelihood (ML). Metode MP mengasumsikan evolusi yang berjalan efisien. Pohon terbaik yang dipilih dalam metode ini yakni pohon yang memiliki paling sedikit perubahan evolusi. Sehingga, apabila terdapat sejumlah cara untuk menghasilkan keadaan seperti sekarang, maka cara yang paling singkat yang akan dipilih. Asumsinya bahwa pohon yang paling bisa menggambarkan keadaan evolusi suatu organisme adalah pohon yang direkonstruksi telah memiliki jumlah mutasi yang paling sedikit untuk mengubah satu sekuens ke sekuens yang lain. Pohon terbaik yang dihasilkan dari algoritme ini adalah pohon yang bersifat paling parsimonious. Algoritme maximum parsimony dapat menyimpulkan adanya perubahan karakter yang kecil dari satu sekuen (Lemey, 2009 dalam Jannah, 2014). 
Konsep metode ML yakni pencarian pola evolusi yang paling mendekati dengan keadaan sesunguhnya. Metode ini tidak mempertahankan pohon dengan langkah evolusi terpendek. Setiap pohon yang terbentuk dihitung untuk kemungkinan yang merefleksikan setiap posisi dari sekuen data dan perhitungan diulang untuk semua situs nukleotida. Algoritme ML menggunakan perhitungan probabilitas kombinasi seluruh karakter dari ancestor, sehingga metode ini lebih kompleks daripada ME dan MP. Pohon dengan probabilitas terbaik ditampilkan sebagai kemungkinan pohon biasanya hanya pohon tetap. Kelemahan dari kelompok metode berdasarkan character-based yakni pencarian satu pohon terbaik diantara jutaan pohon, sehingga waktu komputasi yang diperlukan lebih lama.

Selain algoritme dalam rekonstruksi filogenetik juga menggunakan model evolusi. Terdapat berbagai macam model evolusi yang memiliki asumsi berbeda meliputi Jukes-Cantor one-parameter (JC69), kimura 2-parameter (K80), Felsenstein model (F81 \& F84), Hasegawa-Kishino-Yano (HKY85), Tamura-Nei (TN93), dan General Time Reversible (GTR). Perbedaan yang mendasari model evolusi tersebut yakni frekeunsi setiap jenis nukleotida, laju rerata substitusi dari 1 jenis nukleotida ke nukleotida yang lain, dan frekuensi seberapa sering perubahan dari nukleotida satu ke lainnya dibandingkan dengan perubahan dengan nukleotida yang lain (Page \& Holmes, 1998 dalam Jannah 2014).

Model evolusi JC69 mengamsusikan semua laju perubahan rerata yang sama terhadap semua jenis nukleotida (1/4 untuk setiap jenis nukleotida). Selanjutnya K80 berdasarkan bahwa laju transversi $(\mathrm{A} \longleftrightarrow \mathrm{T}$ dan $\mathrm{C} \longleftrightarrow \mathrm{G})$ lebih rendah dibandingkan laju transisi $(\mathrm{A} \longleftrightarrow \mathrm{G}$ dan $\mathrm{C} \longleftrightarrow \mathrm{T})$. Model tersebut lebih menekankan pada perubahan nilai substitusi berupa transvesi dan transisi. Sedangkan F81 \& F84 mengamsusikan laju transisi dan transversi sama, tetapi laju rerata substitusi dari satu jenis nukleotida ke nukleotida lainnya berbeda. Model HKY, mengakomodir dari kedua model sebelumnya, dengan mempertimbangkan adanya perbedaan laju transisi dan transversi serta laju substitusinya. Perbedaan antar laju dari setiap jenis transisi dan trasversi menjadi dasar model TN93. Selanjutnya model evolusi yang paling kompleks, yakni GTR. Model ini mempertimbangkan adanya perbedaan dalam setiap jenis perubahan nukleotida baik dalam hal laju rerata dan perubahan relatif (Page \& Holmes, 1998 dalam Jannah 2014).

\section{Uji Reliabilitas Pohon Filogenetika}

Evaluasi pohon filogenetika berkaitan dengan uji reliabilitas dari pohon yang direkonstruksi dan uji topologi antara dua atau lebih pohon yang berbeda. Ada dua metode pendekatan yaitu interior branch test (IB) dan Felsenteins Boostrap (FB). Prinsip IB adalah estimasi pohon dengan menguji reliabilitas cabang sebelah dalam (interior branch). Sedangkan FB berprinsip pada repitisi (pengulangan). Dalam prakteknya, 1000 alignment yang baru diciptakan dari data set yang aslinya, maka terdapat 1000 pohon duplikat terbentuk. Nilai bootstrap kemudian akan tampak pada setiap simpul internal dari pohon yang asli, nilai ini menunjukkan jumlah frekuensi dari pola cabang yang tampak pada sebuah simpul. Jika nilai bootstrap lebih dari 950/1000 atau 95\% maka dapat disimpulkan bahwa simpul yang dihasilkan memiliki tingkat kepercayaan yang tinggi. Analisis bootstrap adalah metode yang menguji seberapa baik set data model. Sebagai contoh validitas penyusunan cabang dalam prediksi pohon filogenetik dapat diuji dengan resampled dari kolom dalam multiple sequence alignment untuk membentuk beberapa penjajaran baru. 